\title{
KELAYAKAN USAHA SKALA RUMAH TANGGA GULA SAGU CAIR DI SUNGAI TOHOR KECAMATAN TEBING TINGGI TIMUR KABUPATEN KEPULAUAN MERANTI
}

\author{
Fajar Restuhadi, Rosnita, Roza Yulida, Evy Rossi, \\ Deby Kurnia, Yulia Andriani \\ Fakultas Pertanian, Universitas Riau \\ Kampus Bina Widya Km. 12,5 Simpang Baru Pekanbaru 28293 \\ E-mail: f.restuhadi@lecturer.unri.ac.id
}

\begin{abstract}
Abstrak
Kabupaten Kepuluan Meranti merupakan daerah sentra produksi sagu terbesar di Propinsi Riau. Di kabupaten ini berkembang industri kecil pengolahan sagu menjadi makanan yang bernilai jual tinggi, seperti mie sagu, kerupuk sagu, aneka kue dengan bahan baku sagu. Gula sagu merupakan produk inovasi baru pemanfaatan sagu menjadi gula yang dikembangkan oleh masyarakat di Kabupaten Meranti. Kandungan kadar glucosa gula sagu kalorinya lebih rendah dibandingkan dengan gula tebu, walaupun rasanya tidak terlalu manis, gula sagu ini dapat menjadi gula alternatif yang sehat untuk para penderita diabetes. Selain itu pengembangan gula sagu dapat mensupply kebutuhan masyarakat akan gula, serta dapat mengurangi ketergantungan terhadap gula tebu impor. Sampai saat ini di Kota Pekanbaru sendiri, bahkan di Indonesia belum ada produk gula sagu sejenis yang sudah dipasarkan. Program Bina Desa dirancang selama tiga tahun dan tujuan pada Tahun I telah selesaikan dilaksanakan dengan menghasilkan hal sebagai berikut: Mitra telah mengetahui dan memahami cara membuat produk gula sagu dengan kualitas yang baik dan produk turunannya (minuman dengan bahan baku gula sagu). Bantuan peralatan sebagai bagian paket teknologi pembuatan gula sagu dan produk turunannya juga telah dilakukan. Hasil monitoring dengan mitra diketahui bahwa mitra telah membuat minuman dari gula sagu dengan aneka rasa (rasa yang banyak diminati mocca dan rasa buah) dan telah diperkenalkan pada masyarakat dengan menyuguhkan minuman tersebut pada saat ada kegiatan di kantor desa. Kegiatan lomba cita rasa minuman dengan bahan baku gula sagu yang dilakukan atas kerjasama tim bina desa dengan Pemda Kabupaten Kepulauan Meranti telah mampu memunculkan kreativitas UKM setempat (mitra) dalam menghasil produk minuman yang enak dan layak untuk dikomersilkan. Pada Tahun II ini kegiatan dilanjutkan tujuan sebagai berikut: (1) melakukan analisis kelayakan industri kecil gula sagu cair; (2) pengurusan izin atribut produk (Sertifikat Halal, Depkes dan BPPOM) supaya produk minuman gula sagu dapat dipasarkan ke pasar modern. Dukungan yang besar dari pemerintah setempat menjadi harapan besar bagi pengembangan produk gula sagu kedepannya untuk dapat menjadi usaha masyarakat Kabupaten Kepulauan Meranti dalam rangka meningkatkan perekonomian masyarakat setempat.
\end{abstract}

Kata Kunci: gula sagu cair; kelayakan usaha; industri rumah tangga; RCR

Fajar Restuhadi, Rosnita, Roza Yulida, Evy Rossi, Deby Kurnia, Yulia Andriani | Kelayakan Usaha Skala Rumah Tangga Gula Sagu Cair Di Sunga Tohor Kecamatan Tebing Tinggi Timur Kabupaten Kepulauan Meranti 


\section{PENDAHULUAN}

Pada sektor perkebunan, Kabupaten Kepulauan Meranti dianggap unggul pada komoditi sagunyanya dimana Gubernur Riau telah menobatkan bahwa Kabupaten Kepulauan Meranti sebagai pusat pengembangan tanaman sagu secara nasional. Menurut data Dinas Perkebunan Kabupaten Kepulauan Meranti (2014) Luas area tanaman sagu di Kabupaten Kepulauan Meranti mencapai 38,399 Ha. Perkebunan sagu di Kabupaten Kepulauan Meranti telah menjadi sumber penghasilan utama dengan produksi sagu mencapai 198,162 ton/th dan terdapat 67 kilang sagu.

Kabupaten Kepulauan Meranti terus berusaha mengembangkan potensi perkebunan daerahnya, terutama komoditi sagu. Hal ini dilakukan dengan melakukan pengembangan di beberapa kecamatan yang potensial. Salah satu kecamatan tersebut adalah Kecamatan Tebing Tinggi Barat yang merupakan penghasil sagu kedua terbesar setelah Kecamatan Tebing Tinggi Timur. Luas kebun dan produksi di Kecamatan Tebing Tinggi Timur 16,394 Ha dengan produksi 71,514 ton/tahun dan Tebing Tinggi Barat dengan luas areal 8.951 ha dan produksi 61,371 ton/tahun. Terdapat 14 desa di Kecamatan Tebing Tinggi Barat yang salah satunya adalah Desa Tanjung Peranap yang merupakan salah satu desa dengan potensi yang besar dan sedangkan mengembangkan beberapa produk olahan berbahan baku sagu.

Saat ini tepung sagu juga sedang mulai dikembangkan sagu menjadi gula sagu. Gula sagu merupakan produk inovasi baru pemanfaatan sagu menjadi gula yang dikembangkan oleh masyarakat di Kabupaten Meranti, termasuk Desa Sungai Tohor . Pengembangan gula sagu juga dapat menjadi gula untuk mensupply kebutuhan masyarakat akan gula, serta dapat mengurangi ketergantungan terhadap gula tebu impor. Sampai saat ini di Kota Pekanbaru sendiri, bahkan di Indonesia belum ada produk gula sagu sejenis yang sudah dipasarkan. Dengan demikian, potensi pengolahan 
tepung sagu menjadi gula sagu memungkinkan produk tersebut untuk diangkat menjadi salah satu unit bisnis, Oleh karena itu melalui program desa binaan ini gula sagu menjadi gula alternatif dalam upaya mengurangi ketergantungan terhadap gula tebu sehingga dapat membuka peluang usaha dan kerja baru bagi masyarakat tempatan.

Beberapa hal yang menjadi kendala adalah masalah teknologi pengolahan masyarakat yang masih sederhana, dan beberapa pelatihan yang pernah diikuti oleh anggota kelompok belum dapat diterapkan secara berkelanjutan, dikarenakan oleh peralatan yang dimiliki kelompok masih sederhana, sehingga materi pelatihan tidak dapat praktekkan lagi. Selain belum memadainya teknologi yang dimiliki, produk olahan yang mereka buat belum dapat menjangkau pasar yang lebih luas, lebih banyak hanya dijual disekitar mereka saja.

\section{METODE PELAKSANAAN}

Kegiatan Bina Desa Universitas Riau di Desa Sungai Tohor Kecamatan Tebing Tinggi Barat, direncanakan dalam waktu tiga tahun. Waktu tiga tahun diharapkan dapat dilakukan pembinaan yang berkelanjutan, sehingga usaha pengolahan gula sagu ini benar-benar dapat berkembang dan berkelanjutan. Pelaksanaan kegiatan ini pada satu tahun pelaksanaan dilaksanakan lebih kurang 8 bulan.

Tempat pelaksanaan dari Kegiatan ini dilakukan sesuai dengan kesepakatan dengan masyarakat di Desa Sungai Tohor Kecamatan Tebing Tinggi Barat. Pelaksanaan kegiatan bina desa pada satu tahun pelaksanaan lebih kurang selama 8 bulan dengan pembinaan dan evaluasi dilaksanakan secara berkelanjutan melalui monitoring yang bersifat langsung dan tidak langsung, sebagai berikut: (a) Pengurusan izin/rekomendasi melakukan kegiatan pengabdian dalam rangka pelatihan pada masyarakat berupa izin untuk melakukan kegiatan, (b) Pertemuan antara tim yang akan memberikan kegiatan pelatihan dalam rangka meningkatkan usaha pengolahan gula sagu serta persiapan materi, dan (c) Menghubungi Dinas Pertanian dan Perkebunan, dan masyarakat Desa Sungai Tohor Kecamatan Tebing Tinggi 
Barat dan penentuan jadwal pelaksanaan kegiatan.

Tahap pelaksanaan dilakukan dalam bentuk kegiatan pelatihan tentang pengolahan gula sagu dengan kualitas yang baik dan pengemasan yang menarik. Kegiatan ini menggunakan metode pelatihang diskusi dan pembinaan dengan tahapan sebagai berikut:

1. Pelaksanaan materi pelatihan dengan metode tatap muka dan diskusi dengan kelompok tani, materi disampaikan secara langsung dan diharapkan terjadi interaksi antara anggota kelompok usaha dengan tim pelaksana sehingga materi yang disampaikan dapat lebih dipahami.

2. Diskusi untuk mengetahui sejauh mana anggota kelompok usaha menerima dan memahami materi yang disampaikan.

3. Kegiatan praktek pembuatan gula sagu dan kemasan gula sagu

4. Kegiatan pembinaan dalam bentuk pemantauan dan kunjungan kepada kelompok usaha setelah kegiatan pelatihan, menyangkut tingkat penerapan, bimbingan dan lainnya.

\section{HASIL DAN PEMBAHASAN}

\section{Profil Mitra}

Agroindustri sagu di Desa Sungai Tohor muncul karena sagu merupakan potensi desa tersebut bahkan melimpah apabila musim panen. Kelompok ibu PKK yang diketuai oleh istri Kepala Desa Sungai Tohor sudah lama aktif mengembangkan produk-produk olahan dengan bahan baku sagu untuk meningkatkan ekonoomi masyarakatnya, seperti mie sagu, cendol sagu, kerupuk sagu, dan aneka olahan makanan lainnya dari bahan baku sagu. Sejak tahun 2016, kelompok ibu-ibu PKK Desa Sungai Tohor juga mempelajari cara membuat gula sagu yang diperkenalkan sebelumnya oleh salah satu perguruan tinggi negeri di desa lain.

Kelompok ibu-ibu PKK desa Sungai Tohor terjadi dari seorang ketua kelompok dengan delapan anggotanya. Melalui kelompok ini desa memperkenalkan aneka produk dari sagu ke masyarakat dan membantu masyarakat untuk mengembangkan produk tersebut mejadi usaha yang bernilai 
ekonomis. Melalui ibu-ibu PKK Desa Sungai Tohor diperkenalkan produkproduk dari desa dengan mengikuti berbagai evant-evant baik ditingkat kecamatan, kabupaten, provinsi bahkan sampai pada tingkat nasional. Walaupun ibu-ibu tersebut kebanyakan tingkat pendidikan hanya SD dan SMP, namun mereka memiliki motivasis yang tinggi untuk belajar dan berpartisipasi setiap ada kegiatan desa yang melibatkan ibu-ibu.

Desa Sungai Tohor merupakan salah satu desa percontohan untuk pengembangan sagu di Kabupaten Meranti. Sehingga desa ini termasuk yang banyak dikunjungi oleh pejabat maupun peneliti baik pada tingkat nasional bahkan internasional seperti peneliti dari Jepang. Ini menggambarkan bahwa besarnya potensi sagu desa ini untuk dikembangkan. Untuk itu peran ibu-ibu yang banyak bergerak pada kegiatan pengolahan produk dari sagu ini menjadi bagian penting dalam meningkatkan perekonomian masyarakatnya.

Pengolahan produk sagu oleh ibu-ibu PKK Desa Sungai Tohor memang masih tradisional dan belum dipasarkan secara luas. Pada umumnya produk dibuat pada saat ada permintaan atau ada kegiatan desa yng memerlukan konsumsi dari produk olahan sagu. Oleh karena itu pembinaan dan kemitraan dengan industri memang perlu dilakukan supaya potensi sagu dapat berkembang.

\section{Penyuluhan Tentang Pentingnya Aspek Mutu dan Economic Scale of Production}

Salah satu usaha yang dilakukan untuk memotivasi mitra supaya dapat memulai usaha dan melanjutkan keterampilan yang telah didapatkan adalah dengan memberikan paket teknologi peralatan pembuatan gula sagu dan hasil olahannya. Tim telah memberikan paket teknologi pembuatan gula sagu kepada mittra yang meliputi peralatan yang diperlukan dalam pembuatan gula sagu. Adapun peralatan yang telah diberikan tersebut adalah meliputi : kompor gas, dandang (kukusan), gelas ukur, baskom, panci, saringan, dll yang dibutuhkan untuk proses pembuatan gula sagu dan olahannya. Peralatan sederhana ini dapat membantu masyarakat untuk memproduksi gula cair sagu dengan mutu yang lebih baik dan konsistensi mutu produk yang lebih terjamin. 


\section{Penyuluhan Tentang Pentingnya Aspek Estetika Produk (Kemasan, Label,}

\section{Logo, dan Merek) Terhadap Penerimaan Konsumen}

Mitra juga diberikan pengetahuan tentang teknik pengemasan yang baik dengan memanfaatkan peralatan dengan teknologi modern. Pada waktu kegiatan dilakukan mitra banyak mengetahui tentang teknik pengemasan yang selama ini belum mereka ketahui dan biasanya hanya mereka lihat pada produk-produk olahan yang dijual di pasar modern (supermarket/toko-toko).

\section{Penyuluhan Tentang Pengembangan Beragam Produk Gula Cair Sagu}

Kegiatan yang dilakukan berupa penyuluhan/penyadaran tentang gula sagu yang dapat diolah menjadi berbagai jenis makanan dan minuman yang selain dapat dikonsumsi sendiri juga dapat dijadikan sebagai peluang usaha yang menguntungkan. Hal ini dapat dilakukan dengan besarnya potensi sagu di lingkungan mereka. Selain itu mitra juga disadarkan bahwa aneka produk olahan gula sagu memiliki peluang pasar yang cukup besar jika produk yang mereka hasilkan sesuai dengan selera konsumen.

Pengetahuan diberikan kepada mitra meliputi peningkatan kualitas gula sagu yang dihasilkan mitra menjadi gula sagu cair dan gula sagu serbuk dan menjadi minuman dengan bahan baku gula sagu. Mitra diberikan pengetahuan tentang memproduksi minuman dari gula sagu dengan kualitas yang lebih baik. Berdasarkan informasi dari mitra, mereka belum mengetahui bahwa gula sagu yang dihasilkan dapat diolah menjadi produk lainnya seperti minuman siap saji yang beraneka ragam.

Selain itu bahan-bahan pembuatan minuman gula sagu juga diberikan kepada mitra untuk memotivasi mitra membuat minuman gula sagu dengan aneka rasa, bahan-bahan tersebut meliputi: essence aneka rasa (mocca, strawberry, coklat, melon, dll), natrium benzoat, asam sulfat, dll. Peralatan yang diberikan kepada mitra telah dimanfaatkan untuk memproduksi gula sagu dan minuman gula sagu hasil pelatihan. 

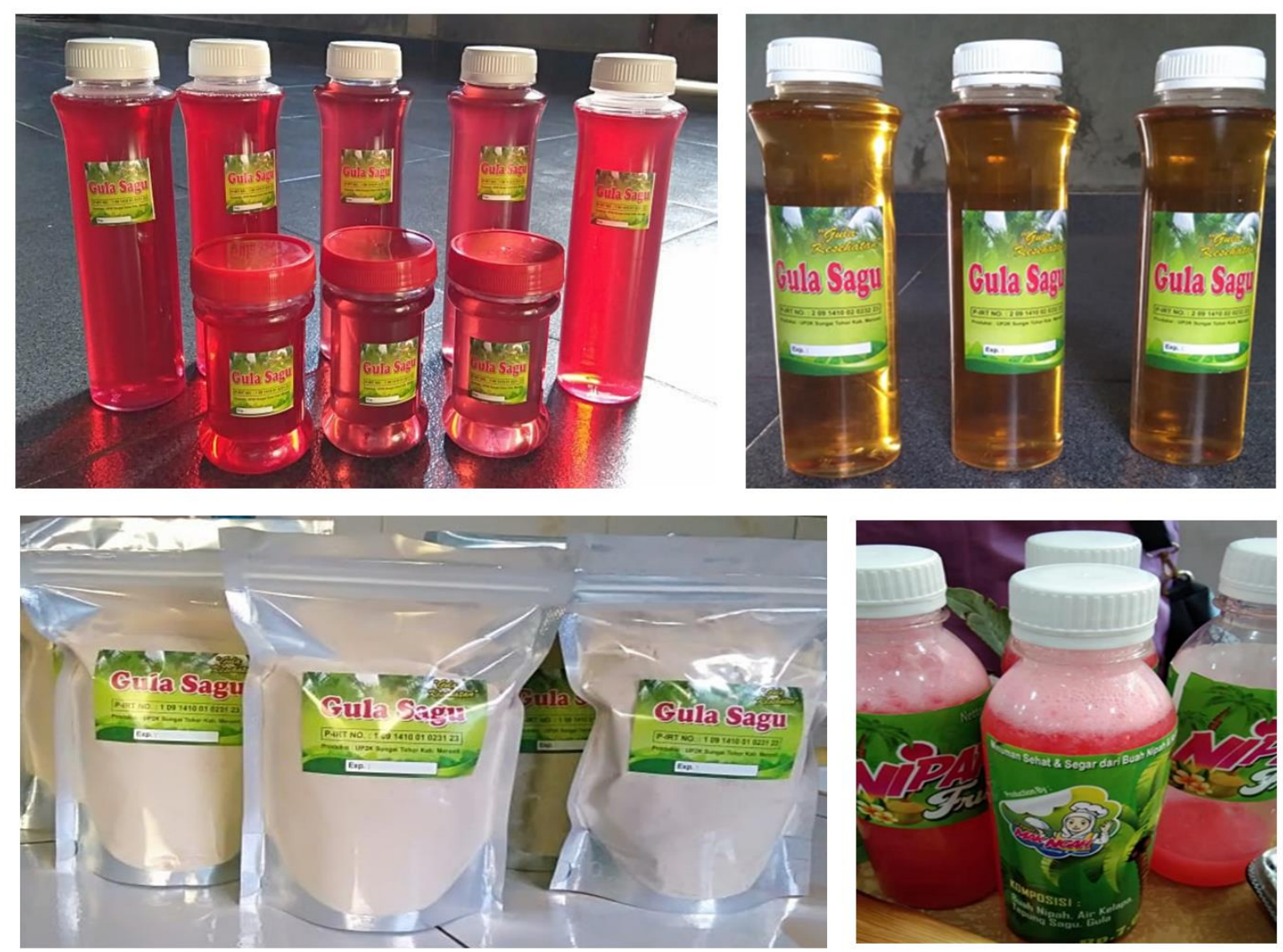

Gambar 1. Hasil penyuluhan untuk perbaikan mutu, kemasan, dan variasi produk gula sagu cair dan serbuk

\section{Penyuluhan Tentang Pentingnya Memahami Perhitungan Analisis Usaha}

Mitra juga disadarkan tentang pentingnya melakukan pembukuan dan analisis usaha agar mereka dapat mengetahui keuntungan yang diperoleh dalam rangka keberlanjutan usaha. Hal ini perlu diketahui mitra agar mitra termotivasi untuk melakukan usaha. Selain itu pengetahuan tentang peluang pasar produk juga diberikan kepada mitra, dan diperkenalkan dengan pemasar produk olahan agar mitra memiliki pengetahuan tentang bagaimana produk yang laku di pasar modern.

\section{Proses Produksi dan Analisis Finansial Industri Gula Cair Sagu yang Dilakukan Masyarakat}

Industri rumah tangga gula cair hanya menggunakan Tenaga Kerja Dalam Keluarga (TKDK). Tenaga kerja yang digunakan oleh pelaku usaha merupakan tenaga kerja wanita yang berjumlah 1 orang. Tenaga kerja tersebut merupakan

Fajar Restuhadi, Rosnita, Roza Yulida, Evy Rossi, Deby Kurnia, Yulia Andriani | Kelayakan Usaha Skala Rumah Tangga Gula Sagu Cair Di Sunga Tohor Kecamatan Tebing Tinggi Timur Kabupaten Kepulauan Meranti 
pelaku usaha itu sendiri. Peralatan yang digunakan dalam proses produksi industri rumah tangga gula cair adalah sebagai berikut:

1. Panci, digunakan untuk merebus bahan - bahan yang digunakan untuk memproduksi gula cair.

2. Sudip, digunakan untuk membolak - balik bahan yang direbus.

3. Baskom, digunakan untuk meletakkan gula cair yang telah matang.

4. Tungku, digunakan untuk memasak gula cair.

Proses produksi masih menggunakan peralatan sederhana panci, sudip, baskom dan tungku. Tahapan pengolahan gula cair terdiri dari pencucian, pengendapan, perebusan, pengendapan, perebusan, pendinginan dan pengemasan. (Sinaga, 2018).

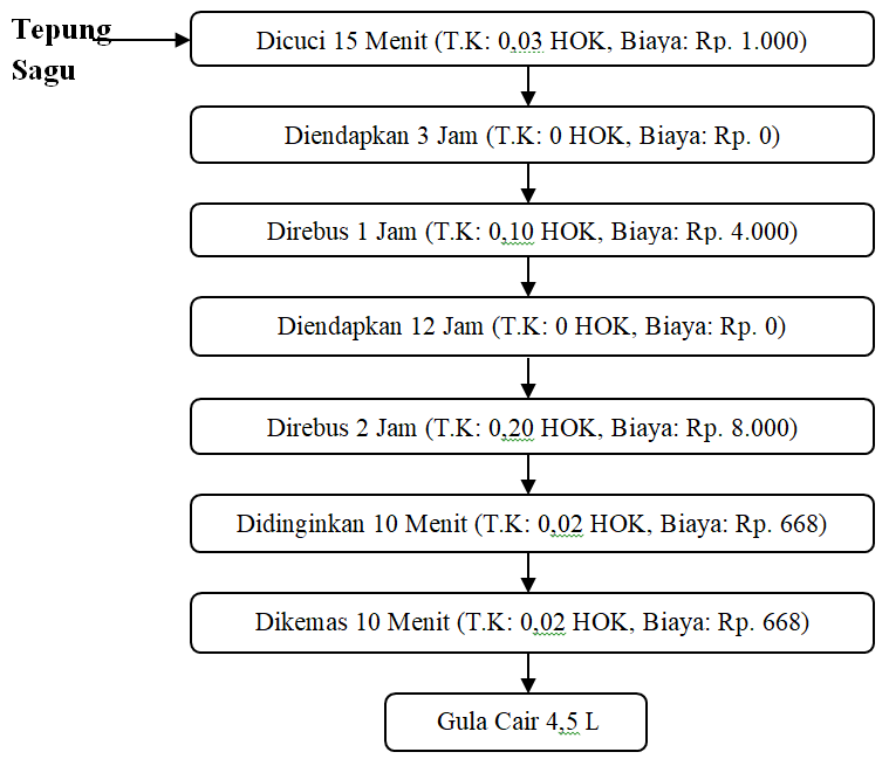

Gambar 2. Tahapan pengolahan gula cair

Rendemen adalah perbandingan jumlah (kuantitas) produk yang dihasilkan oleh pelaku usaha dari jumlah bahan baku yang digunakan. Industri rumah tangga gula cair memiliki rendemen $50 \%$, dimana $1 \mathrm{Kg}$ sagu basah menghasilkan 0,9 L gula cair.

Biaya tetap utama dalam industri ini adalah investasi pengadaan peralatan. Untuk menunjang keberlangsungan industri gula cair diperhitungkan sebagai penyusutan kerja dari alat-alat produksi yang digunakan dalam memproduksi gula 
cair. Untuk mengetahui nilai ekonomis dari masing-masing peralatan yang digunakan dalam proses produksi gula cair, maka dihitung penyusutannya dalam satu kali produksi. Sedangkan biaya variabel adalah biaya yang habis terpakai dalam satu kali produksi. Pada industri rumah tangga gula cair, biaya variabel adalah biaya yang jumlah totalnya sebanding dengan perubahan volume kegiatan.

Tabel 1. Rata-rata biaya yang digunakan dalam satu kali produksi pada industri rumah tangga gula cair di Kecamatan Tebing Tinggi Timur

\begin{tabular}{|c|c|c|c|c|}
\hline \multirow[b]{2}{*}{ No. } & \multirow[b]{2}{*}{ Uraian } & \multicolumn{2}{|l|}{ Nilai } & \multirow[b]{2}{*}{$\begin{array}{l}\text { Persentase } \\
(\%)\end{array}$} \\
\hline & & $\begin{array}{l}\text { Per Proses } \\
\text { Produksi (Rp) }\end{array}$ & $\begin{array}{l}\text { Per } \quad \mathrm{Kg} \\
\text { Bahan Utama } \\
(\mathrm{Rp})\end{array}$ & \\
\hline \multirow[t]{3}{*}{1.} & Biaya Tetap & 15.135 & 3.027 & 23,61 \\
\hline & a. Biaya Tenaga Kerja & 14.336 & 2.867 & 22,36 \\
\hline & $\begin{array}{l}\text { b. Biaya Penyusutan } \\
\text { Peralatan }\end{array}$ & 799 & 160 & 1,25 \\
\hline \multirow[t]{3}{*}{2.} & Biaya Variabel & 48.963 & 9.793 & 76,39 \\
\hline & $\begin{array}{l}\text { a. Biaya Bahan Baku } \\
\text { Utama }\end{array}$ & 10.000 & 2.000 & 15,60 \\
\hline & $\begin{array}{l}\text { b. Biaya } \\
\text { Penunjang }\end{array}$ & 38.963 & 7.793 & 60,79 \\
\hline 3. & Total Biaya Produksi & 64.098 & 12.820 & 100,00 \\
\hline
\end{tabular}

Tabel 1 menunjukkan bahwa rata-rata besaran biaya yang dikeluarkan pelaku usaha industri rumah tangga gula cair sebesar Rp. 64.098 dalam satu kali proses produksi atau sebesar Rp. 12.820 bila dibagi dengan jumlah bahan baku utama yang digunakan. Biaya variabel merupakan biaya yang memiliki besaran biaya yang lebih besar dibandingkan dengan biaya tetap. Biaya variabel terdiri dari 15,60 persen dari biaya bahan baku utama dan 60,79 persen dari biaya bahan penunjang. Sedangkan biaya tetap memiliki total persentase sebesar 23,61 persen yang terdiri dari 22,36 persen dari biaya tenaga kerja dan 1,25 persen dari biaya penyusutan peralatan. Biaya bahan penunjang merupakan biaya terbesar karena masih tingginya harga kedua enzim yang digunakan untuk memecah pati sagu dan 
menjadikannya gula. Biaya penyusutan peralatan merupakan biaya terkecil yang dikeluarkan oleh pelaku usaha industri rumah tangga gula cair.

Rata-rata jumlah produksi pada industri rumah tangga gula cair adalah sebanyak 3 botol/PP dengan isi gula cair sebanyak 1,5 L/botol. Jumlah produksi yang dihasilkan oleh seluruh pelaku usaha memiliki jumlah yang sama dikarenakan pelaku usaha merupakan anggota dari kelompok UP2K. Gula cair dijual dengan harga Rp. 50.000/botol. Penerimaan yang diterima oleh pelaku usaha gula cair yaitu sebesar Rp 150.000/PP. Rata-rata biaya yang dikeluarkan dalam satu kali proses produksi yaitu sebesar Rp. 64.098 maka rata-rata pendapatan yang diterima oleh pelaku usaha yaitu Rp. 85.902/PP atau Rp. 687.216/bulan.

Tabel 2. Rata-rata pendapatan dan efisiensi usaha industri rumah tangga gula cair di Kecamatan Tebing Tinggi

\begin{tabular}{llr}
\hline No. & Uraian & Nilai \\
\hline 1. & Produksi (Botol) & 3,00 \\
2. & Harga (Rp/Botol) & $50.000,00$ \\
3. & Penerimaan (Rp) & $150.000,00$ \\
4. & Biaya Produksi (Rp) & $64.098,00$ \\
5. & Pendapatan (Rp) & $85.902,00$ \\
6. & Efisiensi Usaha (RCR) & 2,34 \\
\hline
\end{tabular}

Berdasarkan hasil perhitungan RCR pada Tabel 2, industri rumah tangga gula cair memiliki nilai RCR >1 yaitu 2,34. Nilai RCR sebesar 2,34 menujukkan bahwa setiap biaya Rp. 1 yang dikeluarkan pelaku usaha industri rumah tangga gula cair akan memberikan penerimaan Rp. 2,34 dan pendapatan Rp. 1,34 sehingga industri rumah tangga gula cair tersebut efisien dan menguntungkan sehingga layak untuk terus diusahakan.

Analisis nilai tambah gula cair bertujuan untuk mengetahui penambahan nilai dari proses pengolahan sagu menjadi gula cair. Nilai tambah dihitung dari besarnya nilai akhir produksi gula cair dikurangi dengan besarnya nilai bahan 
baku dan nilai bahan penunjang serta sumbangan input lain (Sinaga, 2018). Tabel 3 menunjukkan bahwa total produksi gula cair sebesar $\pm 4,50 \mathrm{Kg}$ dihasilkan dari pemakaian bahan baku utama sagu basah sebesar $\pm 5,00 \mathrm{Kg}$. Hasil bagi antara total produk dan bahan baku memberikan nilai faktor konversi sebesar 0,90. Nilai ini menggambarkan bahwa setiap $1 \mathrm{Kg}$ sagu basah menghasilkan gula cair sebesar $0,90 \mathrm{Kg}$.

Tenaga kerja yang dibutuhkan industri rumah tangga gula cair sebesar 0,37 HOK. Koefisien tenaga kerja merupakan hasil bagi antara jumlah tenaga kerja dan bahan baku. Nilai koefisien tenaga kerja industri rumah tangga gula cair adalah 0,06 yang menggambarkan setiap $1 \mathrm{Kg}$ sagu basah yang diolah membutuhkan tenaga kerja sebesar $0,06 \mathrm{HOK}$.

Nilai produk merupakan hasil perkalian antara faktor konversi dengan harga produk sehingga diperoleh nilai produk sebesar Rp. 30.000/Kg. Harga bahan baku sagu basah sebesar Rp. 2.000,00/Kg dan nilai input lainnya sebesar Rp. $7.793 / \mathrm{Kg}$ yang diperoleh dari hasil bagi total sumbangan input lain dengan jumlah bahan baku sagu basah per Kg. Nilai tambah diperoleh dari pengurangan antara nilai produk dengan bahan baku dan nilai input lain sehingga diperoleh nilai tambah gula cair sebesar Rp. 20.207 setiap $1 \mathrm{Kg}$ bahan baku dengan rasio nilai tambah sebesar 67,36 persen.

Tabel 3. Analisis nilai tambah industri rumah tangga gula cair bulan

\begin{tabular}{clr}
\hline No. & \multicolumn{1}{c}{ Variabel } & Nilai \\
\hline I & Output, Input dan Harga & 4,50 \\
\hline 1. & $\begin{array}{l}\text { Total produk (kg/proses } \\
\text { produksi) }\end{array}$ & 5,00 \\
2. & Bahan baku (kg/proses produksi) & 0,37 \\
3. & Tenaga kerja (HOK/proses & 0,90 \\
produksi) & Faktor konversi & 0,07 \\
5. & Koefisien tenaga kerja & $33.333,33$ \\
6. & Harga produk (Rp/kg produk) & $40.000,00$ \\
7. & Upah rata-rata (Rp/HOK)
\end{tabular}




\begin{tabular}{rlr} 
II & Pendapatan dan Keuntungan (Rp/kg Bahan baku) & \\
\hline 8. & Harga bahan baku (Rp/kg) & $2.000,00$ \\
9. & Nilai input lain (Rp/bahan baku) & $7.793,00$ \\
10. & Nilai produk (Rp/kg) & $30.000,00$ \\
11. & a. Nilai tambah (Rp/kg) & $20.207,00$ \\
& b. Rasio nilai tambah (\%) & 67,36 \\
12. & a. Imbalan tenaga kerja (Rp) & $2.800,00$ \\
& b. Bagian tenaga kerja (\%) & 13,86 \\
13. & a. Keuntungan (Rp) & $17.407,00$ \\
& b. Tingkat keuntungan (\%) & 58,02 \\
\hline III & Balas Jasa Faktor Produksi & 10,00 \\
\hline 14. & Margin (Rp/kg) & 27,83 \\
& a. Pendapatan tenaga kerja (\%) & 62,17
\end{tabular}

Imbalan tenaga kerja merupakan hasil perkalian antara koefisien tenaga kerja dengan upah rata - rata sehingga diperoleh imbalan tenaga kerja untuk mengolah setiap $\mathrm{Kg}$ sagu basah sebesar Rp. 2.800. Bagian tenaga kerja yang diterima merupakan hasil bagi antara imbalan tenaga kerja dengan nilai tambah sehingga diperoleh bagian tenaga kerja sebesar 13,86 persen. Keuntungan yang diterima oleh pelaku usaha industri rumah tangga gula cair sebesar Rp. 17.407 dengan tingkat keuntungan sebesar 58,02 persen.

Hasil analisis nilai tambah menunjukkan margin dari bahan baku sagu basah menjadi gula cair yang didistribusikan pada pendapatan tenaga kerja, sumbangan input lain dan keuntungan pengolah. Margin merupakan selisih antara nilai produk dengan harga bahan baku sagu basah per Kg, sehingga diperoleh tiap pengolahan $1 \mathrm{Kg}$ sagu menjadi gula cair diperoleh margin sebesar Rp. 28.000 yang didistribusikan untuk pendapatan tenaga kerja sebesar 10 persen, sumbangan input lain sebesar 27,83 persen dan keuntungan pengolah sebesar 62,17 persen. 


\section{Pemasaran}

Mekanisme pasar merupakan cara menentukan harga dan kuantitas barang yang akan dijual di pasar bebas berdasarkan kekuatan permintaan dan penawaran. Gula serbuk sama halnya dengan gula cair yang merupakan produk baru yang diproduksi masyarakat di Kecamatan Tebing Tinggi Timur, sehingga konsumen dari produk ini masih sedikit dan pasar belum tersedia. Akan tetapi, pengusaha gula serbuk telah memperkenalkan produk ini ke masyarakat luas melalui acara bazar dan pameran serta mempromosikannya dari mulut ke mulut. Sehingga pengusaha industri gula serbuk berproduksi apabila ada pesanan. Sedangkan harga gula cair ditentukan berdasarkan biaya produksi, dimana harga diperoleh dari penjumlahan biaya produksi dan keuntungan yang diinginkan.

\section{KESIMPULAN}

1. Kegiatan bina desa yang telah dilakukan memberikan dampak positif bagi mitra. Mitra telah memiliki pengetahuan dan keterampilan dalam meningkatkan gula sagu dan keterampilan pembuatan minuman dari gula sagu. Mitra telah berhasil membuat minuman gula sagu sesuai dengan pelatihan yang telah dilakukan

2. Mitra telah memiliki keterampilan pengemasan produk minuman gula sagu dengan memanfaatkan paket teknologi pengemasan yang telah diberikan oleh tim.

3. Mitra masih bersemangat untuk melanjutkan kegiatan pembuatan minuman dari gula sagu, dan sedang dalam proses pembinaan untuk menjadikan kegiatan ini menjadi sebuah usaha (home industry).

4. Keterlibatan mitra yang selalu aktif selama proses pelatihan dan pembinaan, serta selalu berkomunikasi dengan tim, dapat menggambarkan bahwa usaha minuman gula sagu ini berpotensi untuk dikembangkan oleh mitra.

\section{SARAN}

1. Pembinaan lebih lanjut dan terus dimotivasi mitra untuk terus melanjutkan keterampilan yang telah didapatkan untuk menjadi sebuah usaha yang menguntungkan, merupakan kegiatan lanjutan yang perlu dilakukan oleh tim.

2. Mengingat potensi usaha gula sagu dan minuman gula sagu dapat menjadi 
usaha yang menguntungkan, serta dapat membuka peluang kerja dan usaha masyarakat, maka perhatian pemerintah dalam memfasilitasi masyarakat untuk turut mengembangkan usaha gula sagu dan produk olahannya menjadi produk unggulan dari Kabupataen Meranti sangat diperlukan.

\section{DAFTAR PUSTAKA}

Chalid, Ida Rahmi. 2006. Peranan Perempuan Tani dalam Pemberdayaan Ekonomi Keluarga Petani Miskin (Studi Kasus Keluarga Petani Sawah Tadah Hujan di Desa Bonto Mate’ne Kecamatan Mandai Kabupaten Maros. Tesis Program Pascasarjana. Universitas Hasanuddin Makassar.

Dian, Nina Nita. 2010. Analisis Usaha Industri Rumah Tangga Keripik Tempe Di Kabupaten Wonogiri. Skripsi Fakultas Pertanian, Universitas Sebelas Maret.

Darmawan, T., dan Masroh, A.H. 2004. Pentingnya Nilai Tambah Produk Pangan Dalam Buku Pertanian Mandiri. Penebar Swadaya. Jakarta.

Dinas Kehutanan dan Perkebunan Kabupaten Kepulauan Meranti. 2015. Luas Areal, Jumlah Petani dan Produksi/Produktivitas Perkebunan. Dinas Kehutanan dan Perkebunan Kabupaten Kepulauan Meranti. Selat Panjang.

Dinas Perindustrian, Perdagangan, Koperasi, Usaha Mikro, Kecil dan Menengah Kabupaten Kepulauan Meranti. 2016. Daftar IKM Pengolahan Berbahan Baku Sagu di Kabupaten Kepulauan Meranti. Dinas Perindustrian, Perdagangan, Koperasi, Usaha Mikro, Kecil dan Menengah Kabupaten Kepulauan Meranti. Selat Panjang.

Elizabeth, R. 2008. Peran Ganda Wanita Tani dalam Mencapai Ketahanan Pangan. Rumah Tangga di Pedesaan, Iptek. Jurnal Iptek Tanaman Pangan Vol.3 No.1

Fadila, Ila. 2011. Potensi Sagu dalam Upaya Diversifikasi Pangan. Universitas Terbuka. Tangerang Selatan.

Fahroji. 2011. Pengolahan Sagu. Balai Pengkajian Teknologi Pertanian (BPTP)

Riau. Pekanbaru.

Fajar Restuhadi, Rosnita, Roza Yulida, Evy Rossi, Deby Kurnia, Yulia Andriani | Kelayakan Usaha Skala Rumah Tangga Gula Sagu Cair Di Sunga Tohor Kecamatan Tebing Tinggi Timur Kabupaten Kepulauan Meranti 
Hariyanto, Bambang. 2011. Manfaat Tanaman Sagu (Metroxylon sp) dalam Penyediaan Pangan dan dalam Pengendalian Kualitas Lingkungan. Jurnal Teknik Lingkungan. Volume 12(2): 143 - 152.

Rosnita, Yulida Roza, dan Andriani Yulia, 2017. Penyuluhan Sagu dalam Mendukung Ketersediaan Pangan Di Kabupaten Kepulauan Meranti. Prosiding Seminar Nasional dan Rapat Tahunan Dekan Bidang Ilmu Pertanian BKS-PTN Wilayah Barat "Mendorong Kedaulatan Pangan Melalui Pengembangan Sumber Daya Lokal. Universitas Bangka Belitung 20-21 Juli 2017.

Rosnita, Kausar, Yulida Roza, dkk, 2016. Hubungan keberdayaan petani dengan kemandirian petani petani sagu di kecamatan Tebing Tinggi Timur Kabupaten Kepulauan Meranti. Prosiding Seminar Nasional "Peranan Ristek dalam Meningkatkan Daya Saing Sumber Daya Lokal, tanggal 1 Agustus 2016 di Universitas Pasir Pangaraian.

Sinaga, Harizona. 2018. Analisis Usaha Agroindustri Berbasis Sagu di Kecamatan Tebing Tinggi Timur Kabupaten Kepulauan Meranti. Skripsi Fakultas Pertanian Universitas Riau.

Sipahutar, Natalia. 2016. Analisis Perkembangan Industri Kecil Sepatu Di Kota Medan. Skripsi Fakultas Ekonomi danBisnis, Universitas Sumatera Utara.

Situmorang, Elisabeth. 2014. Keberdayaan Kelompok Wanitatani Melalui Pengembangan Usaha Agribisnis Perdesaan (Puap), (Studi Kasus : Usaha pada Agribisnis Sayuran di Desa Pandan Wangi Kecamatan Peranap, Kabupaten Indragiri Hulu). Skripsi Fakultas Pertanian Universitas Riau, Pekanbaru.

Soekartawi. 1990. Teori Ekonomi Produksi. PT Raja Grafindo Persada, Jakarta. 